\title{
High Level Activation of Vitamin B1 Biosynthesis Genes in Haustoria of the Rust Fungus Uromyces fabae
}

\author{
Jürgen Sohn, Ralf T. Voegele, Kurt Mendgen, and Matthias Hahn \\ Fachbereich Biologie, Phytopathologie, Universität Konstanz, D-78457 Konstanz, Germany \\ Accepted 7 March 2000.
}

In the rust fungus Uromyces fabae, the transition from the early stages of host plant invasion toward parasitic growth is accompanied by the activation of many genes $(P I G s=$ in planta induced genes). Two of them, PIGI (= THI1) and PIG4 (= THI2), were found to be highly transcribed in haustoria, and are homologous to genes involved in thiamine (vitamin B1) biosynthesis in yeast. Their functional identity was confirmed by complementation of Schizosaccharomyces pombe thiamine auxotrophic thi3 (nmt1) and thi2 (nmt2) mutants, respectively. In contrast to thiamine biosynthesis genes of other fungi that are completely suppressed by thiamine, THI1 and THI2 expression was not affected by the addition of thiamine to rust hyphae grown either in vitro or in planta. Immunoblot analysis revealed decreasing amounts of THI1p in extracts from spores, germlings, and in vitro-grown infection structures with increasing time after inoculation. Immunofluorescence microscopy of rust-infected leaves detected high concentrations of THI1p in haustoria, and only low amounts in intercellular hyphae. In the sporulating mycelium, THI1p was found in the basal hyphae of the uredia, but not in the pedicels and only at very low levels in uredospores. These data indicate that the haustorium is an essential structure of the biotrophic rust mycelium not only for nutrient uptake but also for the biosynthesis of metabolites such as thiamine.

Additional keywords: plant-pathogenic, Vicia faba.

Thiamine diphosphate (vitamin B1) is a cofactor required for the activity of several enzymes of the central carbon metabolism, such as pyruvate dehydrogenase, pyruvate decarboxylase, $\alpha$-ketoglutarate decarboxylase, and transketolase. In yeast cells, biosynthesis of thiamine occurs via two precursor molecules that are derivatives of thiazol and pyrimidine (Hohmann and Meacock 1998). These are phosphorylated and then condensed to form thiamine phosphate, which is subsequently converted to the enzyme cofactor thiamine diphosphate. Whereas the later steps of thiamine biosynthesis are well characterized, the origin of the precursors is not well established. In Schizosaccharomyces pombe and Saccharomyces cerevisiae, several thiamine auxotrophic mutants have been isolated, and the corresponding thiamine biosynthesis genes

Corresponding author: M. Hahn; Fax: + 497531 883035; E-mail: matthias.hahn@uni-konstanz.de

Nucleotide and/or amino acid sequence data are to be found at GenBank at accession numbers AJ250426 (THI1) and AJ250427 (THI2). have been characterized (Hohmann and Meacock 1998). In $S$. cerevisiae, biosynthesis and uptake of thiamine are strongly repressed by thiamine (Manetti et al. 1994). Repression occurs mainly at the transcriptional level and involves several regulatory genes (Hohmann and Meacock 1998).

Rust fungi are obligate plant parasites that depend on living host tissue for growth. Little is known about their nutritional demands during parasitic growth. Feeding experiments with radioactively labeled metabolites have shown that rusts take up sugars and amino acids from their host plants (Mendgen 1981). The establishment of axenic cultures from a few rust species such as Puccinia graminis f. sp. tritici and Melampsora lini have revealed their ability to grow on defined mineral media containing sugars and amino acids, supplemented either with low concentrations of yeast extract (Williams 1984) or peptone (Coffey and Shaw 1972), or with some vitamins (Fasters et al. 1993). Thus, the obligate parasitic lifestyle of rust fungi cannot be explained by strongly handicapped biosynthetic capabilities. Instead, it was proposed that development of rust fungi is tightly linked to essential signals provided by the host plant (Heath and Skalamera 1997).

To investigate the metabolism of rust fungi during biotrophic growth, a molecular genetic approach has been taken by our group. From a haustorium-specific cDNA library, isolated from the broad bean rust Uromyces fabae, 32 cDNAs were isolated that showed preferential expression during fungal growth in planta (Hahn and Mendgen 1997). Two of these cDNAs (corresponding to genes named PIGl (= THII) and PIG4 (= THI2)) are highly similar to fungal genes involved in thiamine biosynthesis (Hahn and Mendgen 1997). In this paper, we present a structural and functional analysis of these genes, including their regulation, and describe the expression of the THI1-encoded protein and its localization within the biotrophic mycelium.

\section{RESULTS}

Structural analysis of THI1 and THI2.

The cDNA sequence of THII (PIGl) has already been published (Hahn and Mendgen 1997). The sequence of THI2 (PIG4) cDNA reveals an open reading frame of 1,014 bp, encoding a protein (THI2p) with a calculated molecular mass of $36.2 \mathrm{kDa}$. Similar to THI1p, THI2p shows unambiguous homology to fungal and plant proteins involved in thiamine biosynthesis (Fig. 1). For instance, THI2p is $63.0 \%$ identical to the thi2 (nmt2)-encoded protein of Schizosaccharomyces pombe, and $49.5 \%$ identical to the thi4-encoded protein of Arabidopsis 
thaliana. Based on these homologies, THI1p is likely to be involved in the synthesis of the pyrimidine moiety, and THI $2 p$ in the synthesis of the thiazol moiety of thiamine (Fig. 2).

With THII and THI2 cDNAs as hybridization probes, the corresponding genomic clones were isolated from an EMBL3 bacteriophage library of Uromyces fabae total DNA. EMBL3 clones with inserts of about $17 \mathrm{~kb}$ (THI1) and $16 \mathrm{~kb}$ (THI2) were taken for sequencing, with subclones and polymerase chain reaction (PCR) fragments used as templates. From THII, 5,180 bp were sequenced (accession no. AJ250426), covering $1,762 \mathrm{bp}$ upstream of the transcriptional start site, 2,365 bp containing the transcribed region including introns, and 1,053 bp representing the $3^{\prime}$ region of the gene. From THI2, 4,833 bp were sequenced (accession no. AJ250427), covering 2,045 bp upstream of the transcriptional start site, $1,709 \mathrm{bp}$ containing the transcribed region including introns, and 1,072 bp representing the $3^{\prime}$ region of the gene. THII contains 9 introns ranging in size from 69 to 244 bp (average size $100 \mathrm{bp}$ ), and THI2 contains 7 introns ranging in size from 73 to $102 \mathrm{bp}$ (average size $85 \mathrm{bp}$ ). Transcriptional start points were mapped by primer extension $137 \mathrm{bp}$ (THII) and $96 \mathrm{bp}$ (THI2) upstream of the presumptive start codons (Fig. 3). Searches for control elements revealed putative TATA boxes $35 \mathrm{bp}$ (THI1) and $37 \mathrm{bp}$ (THI2) upstream of the transcriptional start points, but no other apparent features or similarities in the promoter regions of THII and THI2.

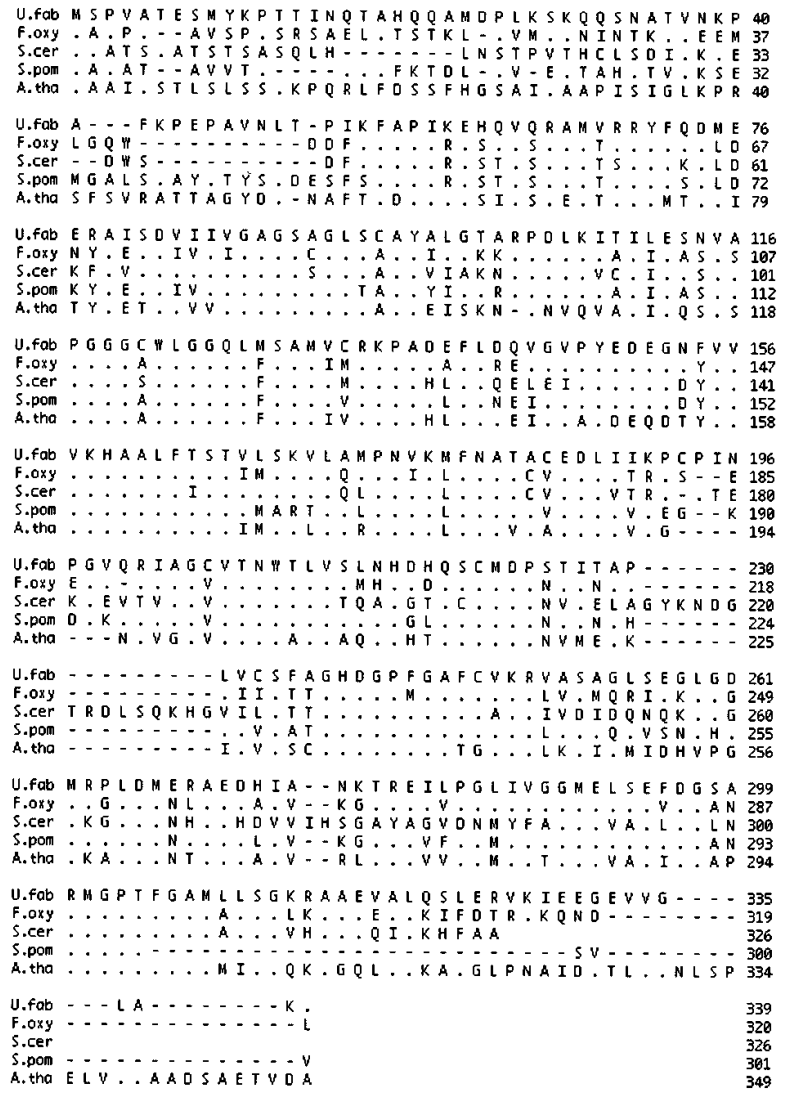

Fig. 1. Alignment of the predicted Uromyces fabae THI2p amino acid sequence with protein sequences encoded by Fusarium oxysporum THI4 (F.oxy, accession number P23618), Saccharomyces cerevisiae THI4 (S.cer, P32318), Schizosaccharomyces pombe THI2 (S.pom, P40998), and Arabidopsis thaliana THI4 (A.tha, Q38814). Identical residues are indicated by dots and missing residues by dashes.

\section{Functional complementation of $S$. pombe} thiamine mutants.

To prove the identity of THII and THI2, thiamine auxotrophic mutants of fission yeast were used for complementa-

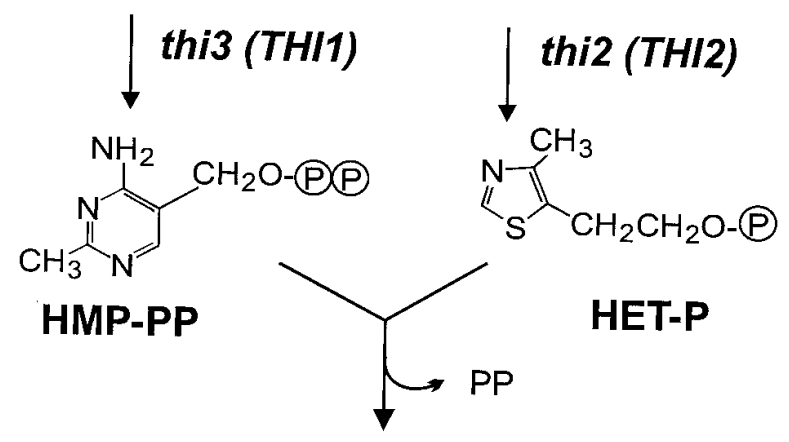

Thiamine-P

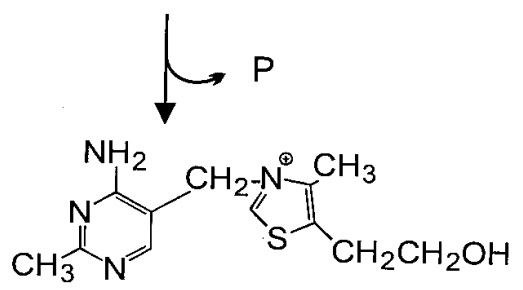

Thiamine

Fig. 2. Thiamine biosynthesis in fungi. The presumptive roles of the Schizosaccaromyces pombe genes thi3 (nmt 1$)$ and thi2 (nmt2), and of the corresponding Uromyces fabae genes THII and THI2 (in parentheses) are indicated. HMP-PP: 2-methyl-4-amino-5-hydroxymethylpyrimidine-pyrophosphate; HET-P: 4-methyl-5-(B-hydroxyethyl)thiazol phosphate.

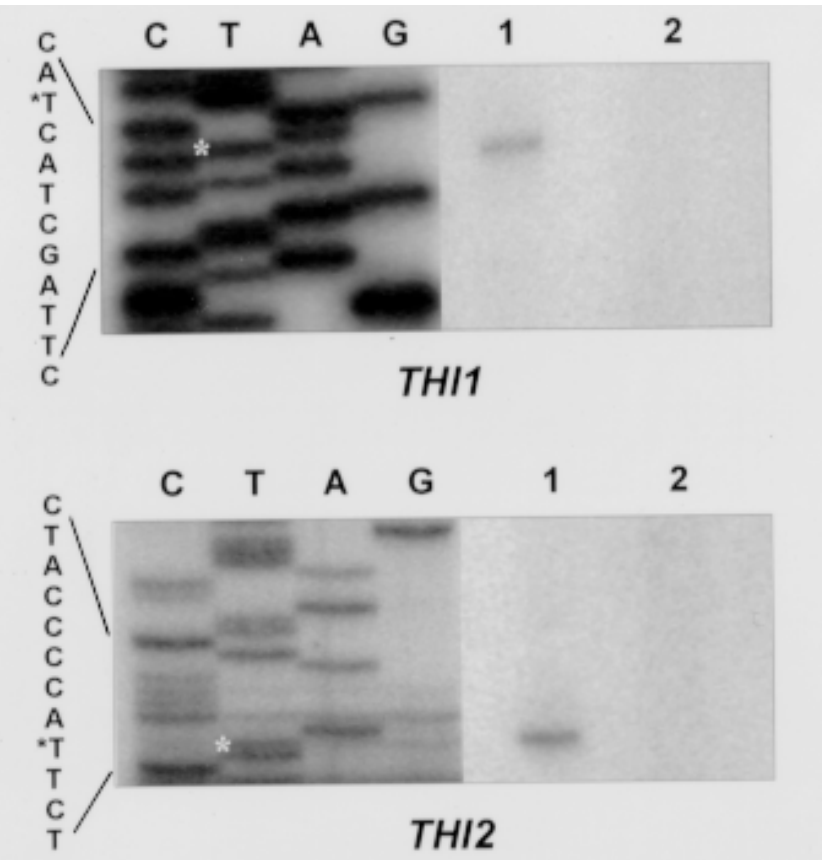

Fig. 3. Determination of the $5^{\prime}$ ends of THII and THI2 mRNAs by primer extension. In the neighboring sequence ladders, bases flanking the transcriptional start points (asterisks) are indicated. Lane 1: rustinfected leaves (6 days post inoculation); lane 2: noninfected leaves. 
tion studies. cDNAs containing the complete coding regions of THII and THI2 were cloned into the S. pombe vectors pSAP-E and pSAP-N, in both expressing and nonexpressing orientations (see Materials and Methods). The recombinant plasmids, as well as the corresponding vectors, were transformed into $S$. pombe strains auxotrophic for leucine and vitamin B1: pSAP-N::THII and pSAP-N::THIIinv into strain thi3-1 leu1-32, and pSAP-E::THI2 and pSAP-E::THI2inv into strain thi2-22 leul-32. Leucine prototrophic transformants were obtained and tested for their ability to grow on thiaminefree minimal medium. Only those transformants that carried the THI1 (strain thi3-1 leu1-32) or THI2 (strain thi2-22 leul32) cDNAs in the expressing orientation were able to grow in the absence of thiamine. In contrast, transformants carrying the vectors only or the cDNAs in inverse orientations did not grow unless thiamine was provided (Fig. 4). Thus, THII and THI2 were shown to complement their $S$. pombe homologs thi3 and thi2, respectively.

\section{Regulation of THII and THI2 expression.}

The isolation of THII and THI2 cDNA clones was based on their phase-specific expression in haustoria. The pattern of THI1 mRNA expression during rust development has been described (Hahn and Mendgen 1997). A very similar expression pattern was observed for THI2: No transcripts were detected in uredospores and in vitro-differentiated infection structures up to $18 \mathrm{~h}$ after germination. Low transcript levels were detected in 18-and 24-h-old in vitro infection structures, and very high mRNA levels in haustoria and rust-infected $\mathrm{Vi}$ cia faba leaves (Fig. 5). Thus, THII and THI2 expression begins at a stage of rust development that normally occurs in planta, during formation of haustorial mother cells (Deising et

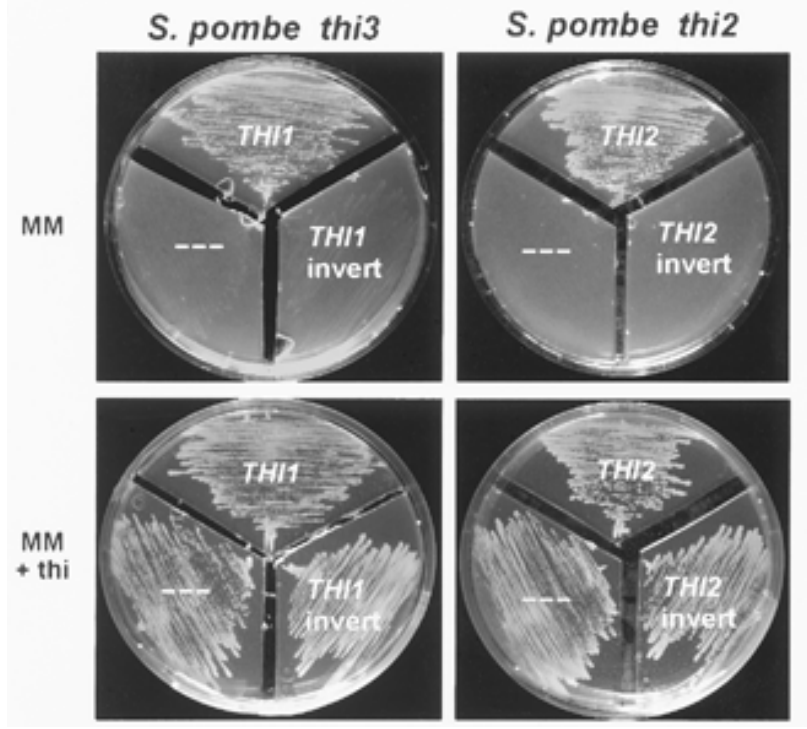

Fig. 4. Complementation of Schizosaccaromyces pombe thiamine auxotrophic mutants with plasmids carrying THI1 or THI2 cDNAs from Uromyces fabae. On each sector of the agar plates a strain carrying one of the following plasmids was streaked out: In the $S$. pombe strain thi3-1 leu1-32 (left panels) pSAP-N (---), pSAP-N::THI1 (THI1), and pSAP$\mathrm{N}:$ THIlinv (THI1 invert); in S. pombe strain thi2-22 1eu1-32 (right panels) pSAP-E (---), pSAP-E::THI2 (THI2), and pSAP-N::THI2inv (THI2 invert). The plates contained minimal medium alone (MM) or supplemented with $50 \mathrm{nM}$ thiamine $(\mathrm{MM}+$ thi). al. 1991). While this initial induction is independent of signals from the plant, maximal expression occurs only in the biotrophic growth phase.

The following experiments were performed to test whether the expression of THII and THI2 can be suppressed by thiamine in a similar way as the homologous genes of other fungi, which are completely turned off at micromolar concentrations of vitamin B1 (Maundrell 1990; Cary and Bhatnagar 1995). Rust infection structures developed in vitro and in rustinfected broad bean leaves were treated with various concentrations of thiamine and the transcript levels of the THI genes were compared with the levels found in untreated controls (see Materials and Methods). In 24-h-old infection structures, which show easily detectable mRNA levels of THII (Hahn and Mendgen 1997) and THI2 (Fig. 5), treatment with $100 \mu \mathrm{M}$ thiamine did not alter the transcript levels found with watertreated structures (Fig. 6A). Similarly, the high expression of the genes in rust-infected leaves remained unchanged after daily treatments of the leaves with thiamine concentrations up to $1 \mathrm{mM}$ (Fig. 6B). These data demonstrate that, in U. fabae, expression of thiamine biosynthesis genes is unaffected by the presence of exogenous thiamine.

\section{Immunological detection of THI1p.}

The occurrence of the THII-encoded protein in rust-infected leaves and in various stages of rust development was analyzed with polyclonal antibodies generated against histidine-tagged THI1p produced in Escherichia coli (see Materials and Methods). In a time course experiment, THI1p was not detected by Western blot (immunoblot) analysis in protein extracts from rust-infected leaves until 5 days after inoculation with $U$. fabae (Fig. 7A). THI1p was also detected in spores, and in progressively lower concentrations in germlings and infection

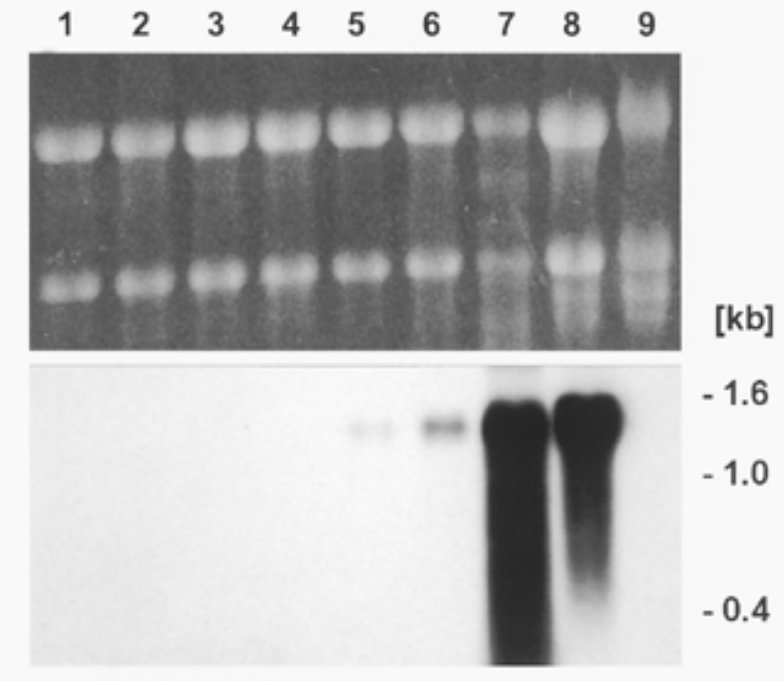

Fig. 5. THI2 transcript levels during rust development. Top panel: ethidium bromide-stained agarose gel before transfer of the RNA. Bottom panel: autoradiograph with hybridization signals after chemiluminescent detection of digoxigenin-labeled THI2-cDNA probe. Lane 1: nongerminated uredospores; lane 2: $4 \mathrm{~h}$ germinated spores; lanes 3 to 6: in vitro-grown infection structures $6,12,18$, and $24 \mathrm{~h}$ post inoculation (pi), respectively; lane 7: isolated haustoria; lane 8: rust-infected leaves ( 5 days pi); lane 9 : noninfected leaves. Five micrograms of total RNA was loaded per lane. 
structures of increasing age (Fig. 7B). With a 25-fold lower protein concentration, THI $1 \mathrm{p}$ was easily detected in haustoria (Fig. 7B, lane H). Immunofluorescence microscopy of rustinfected leaves also revealed very strong labeling of THI1p in haustoria and young haustorial mother cells, whereas intercellular hyphae were significantly weaker labeled (Fig. 8A, B). In leaves containing sporulating mycelium, THI1p was also found in the basal sporogenous hyphae of the uredia. In contrast, no fluorescence was detected in the adjacent pedicels and only barely detectable levels were found in the uredospores (Fig. 8C). Controls with pre-immune serum did not show any labeling of infected leaf tissue.

\section{DISCUSSION}

In rust fungi, the early stages of development, i.e., germination and infection structure formation up to the primary haustorial mother cell, can occur in the absence of the host plant and of any supplied nutrients, due to large nutrient reserves of the uredospores (Staples and Macko 1984; Deising et al. 1991). In contrast, growth of the biotrophic mycelium is dependent on metabolites provided by the host. The drastic changes in gene expression that are observed when Uromyces fabae enters the parasitic growth stage (Hahn and Mendgen 1997) probably reflect the molecular and cytological adaptations of the fungus to the biotrophic mode of growth. Among the in planta induced genes (PIGs), the thiamine biosynthesis genes THII and THI2 are the most highly expressed in haustoria, together representing approximately $5 \%$ of the haustorial mRNA (Hahn and Mendgen 1997). A similarly high level of

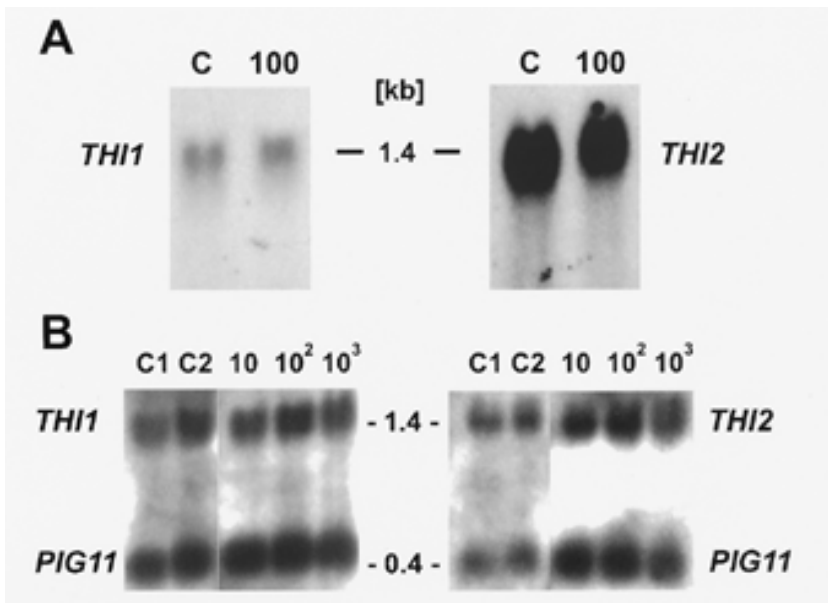

Fig. 6. $T H I 1$ and $T H I 2$ transcript levels after treatment with thiamine. A, Infection structures ( $24 \mathrm{~h}$ old) grown on polyethylene membranes. Distilled water (C) or $100 \mu \mathrm{M}$ thiamine (100) was sprayed onto the spores before germination. Hybridization was performed with digoxigeninlabeled THI1 (left) or THI2 (right) cDNA probes. Ten micrograms of total fungal RNA was loaded per lane. B, Rust-infected leaves. Infiltration treatments were performed daily as described in Materials and Methods. To confirm similar loading and quality of RNA in all samples, THI1 (left) and THI2 (right) probes were mixed with a cDNA probe for PIG11, a gene encoding a putative metallothionein (Hahn and Mendgen 1997). PIG11 was found to be a suitable marker for the amount of fungal mycelium in rust-infected leaves (J. Sohn and M. Hahn, unpublished data). C1: Noninfiltrated infected leaves. C2: Water-infiltrated infected leaves. $10,10^{2}, 10^{3}$ : Infected leaves infiltrated with various concentrations $(\mu \mathrm{M})$ of thiamine. Ten micrograms of total leaf RNA was loaded per lane. expression of S. pombe genes homologous to THI1 (thi3 / $n m t 1$ ) and THI2 (thi2 / nmt2) was observed when yeast cells were grown in the absence of thiamine (Maundrell 1990; Praekelt and Meacock 1992; Manetti et al. 1994). The most likely interpretation is that $U$. fabae performs thiamine biosynthesis very actively only during parasitic growth, presumably because this vitamin is growth limiting and not available from the host plant.

The expression patterns of THII and THI2 are very similar: No significant amounts of transcripts were detected until $18 \mathrm{~h}$ after germination. The mRNA levels increased in 18- and 24h-old, in vitro-grown infection structures, and accumulated to very high concentrations in haustoria and rust-infected leaves. These data indicate that the activation of these genes is coupled to fungal development, but not directly induced by chemical host factors. In contrast to what occurs in several saprophytic fungi, thiamine biosynthesis in $U$. fabae is not suppressed by exogenously added thiamine. Our experiments could not distinguish whether this was due to the absence of a repressive effect or the inability of the rust hyphae to take up thiamine, possibly due to the lack of an appropriate transport system. In $S$. cerevisiae, thiamine uptake was shown to be mediated by a specific transporter belonging to the major facilitator superfamily (Enjo et al. 1997; Singleton 1997).

Sequence analysis of THII and THI2 revealed the presence of 9 and 7 introns, respectively. Based on the mRNA lengths of THII (1,466 bp) and THI2 (1,353 bp), this corresponds to an average exon length of 147 bp (THII) and 169 bp (THI2). Because of their similar expression pattern and the involvement in the same biosynthesis pathway, it was expected that THII and THI2 share common regulatory elements. However, the sequences upstream of the transcriptional start sites of THII and THI2 did not reveal obvious promoter elements or any other similar sequences. To test whether these genes are subject to common regulation, DNA-protein binding studies need to be performed.

While no transcripts were observed in spores and early infection structures, $\mathrm{THI}$-encoded protein was detected in these samples by immunoblot analysis. Nevertheless, the decrease of THI1p during germination and infection structure formation indicates that the protein is subject to degradation during the

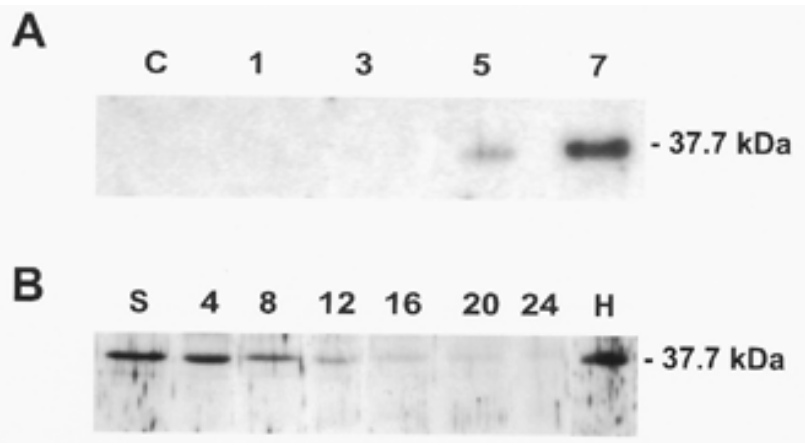

Fig. 7. Detection of THI1p by immunoblot analysis. A, Infected leaves. Numbers indicate days after inoculation with Uromyces fabae. C: Noninfected leaves. Twenty micrograms of total protein was loaded per lane. Antiserum dilution was 1:7.500. B, U. fabae at various stages of development. S: uredospores. Numbers indicate times after inoculation (4 to $24 \mathrm{~h}$ ) of in vitro-grown infection structures. H: haustoria. Fifty micrograms of total protein was loaded on each lane, except for lane $\mathrm{H}(2 \mu \mathrm{g})$. Antiserum dilution was 1:1.000. 
first hours of development. Apparently, the fungus concentrates its metabolic efforts during early development on the requirements of the invasion process, without investing in costly biosynthetic activities. In the biotrophic rust mycelium, THI1p levels are much higher, consistent with the very high THII mRNA level found in planta. The particularly strong THI1p labeling in haustoria indicates that they are the major sites of thiamine biosynthesis. In contrast, intercellular hyphae showed only weak labeling, whereas an intermediate level of fluorescence was observed in the basal cell layer of uredia. The differences of labeling were partially due to vacuolization, which was pronounced in most hyphae but not in haustoria. Thus, THI1 shows a distinct pattern of cellular distribution.

There is evidence that plant-pathogenic fungi are under nutrient limitation during biotrophic growth within the plant, based on the low apoplastic metabolite concentrations (Lohaus et al. 1995) and on the observations that starvationinduced genes in Cladosporium fulvum and Magnaporthe grisea are also activated during growth in planta (Coleman et al. 1997; Talbot et al. 1997). Increased permeability of host membranes has been reported to be induced by powdery mildew infection (Aked and Hall 1993) but not by rust infection (Farrar and Lewis 1987). Low apoplastic concentrations could be one explanation for the evolution of haustoria if they form an interface at which increased metabolite efflux from the host cell occurs, due to an increase in cytoplasmic solute concentration or plasma membrane permeability (Patrick 1989). Evidence for the latter has been obtained by cytochemical studies that indicate that the host-derived extrahaustorial membrane might be depolarized due to the lack of plasma membrane ATPase activity (Spencer-Phillips and Gay 1981; Baka et al. 1995).

The observations of haustorium-specific expression of a putative amino acid transporter (Hahn et al. 1997) and a hexose transporter (R. Voegele, M. Hahn, and K. Mendgen, unpublished data) in $U$. fabae represent molecular evidence for a prominent role of rust haustoria in nutrient absorption. The data presented in this paper indicate that haustoria also perform biosyntheses of metabolites that are not available in sufficient amounts from the plant. Based on the very high and rather specific expression of THII and THI2 in haustoria, we hypothesize that they synthesize enough thiamine to supply it to other parts of the biotrophic mycelium. Such a privileged role of haustoria could explain the difficulties in establishing axenic cultures with rust fungi, which has only been achieved with a few species (Mendgen 1981; Fasters et al. 1993). Because such cultures never produce haustoria, they might be strongly restricted in both the uptake and the biosynthesis of

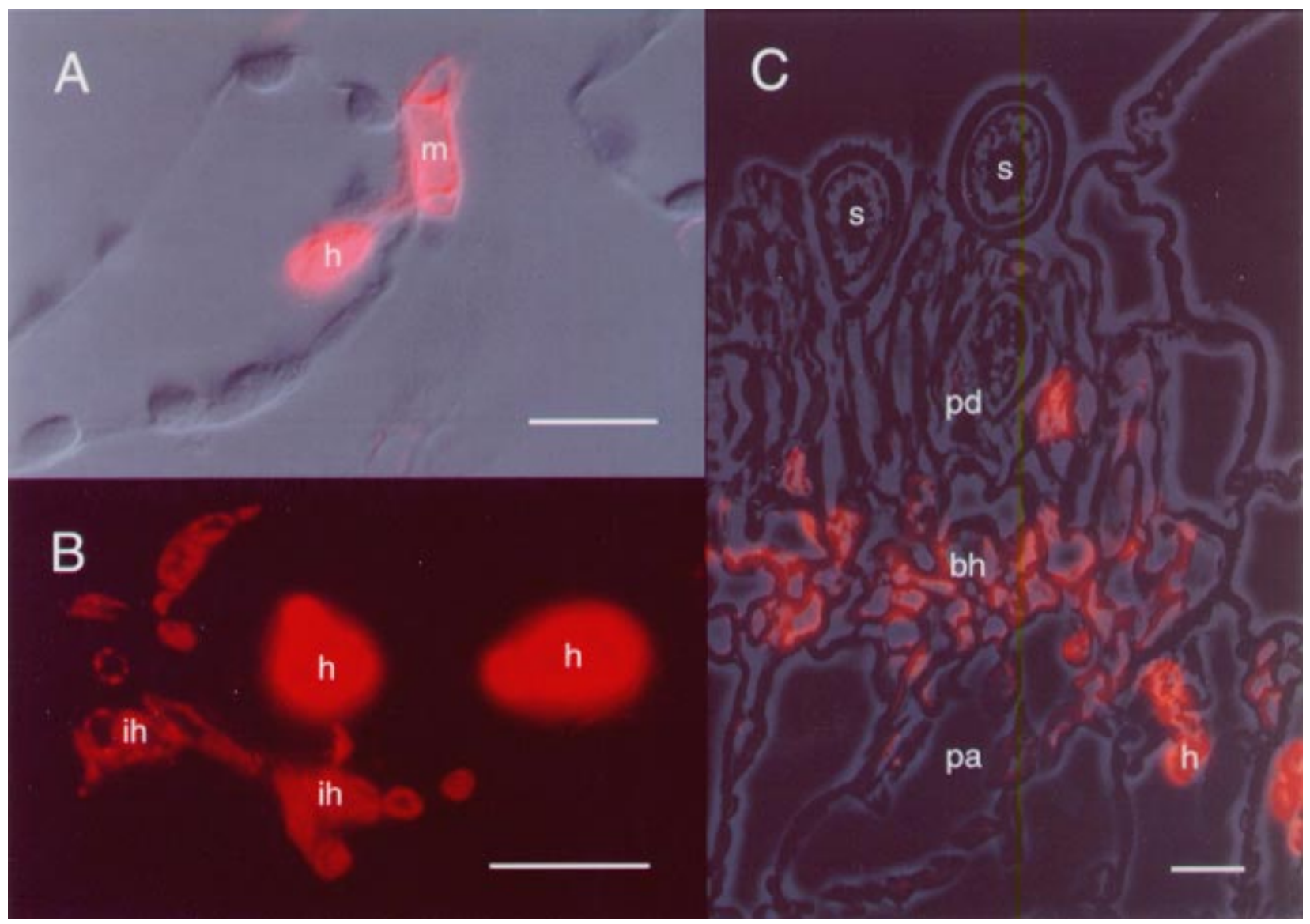

Fig. 8. Localization of THI1p in rust-infected leaves by immunofluorescence microscopy. A, Fluorescently labeled haustorial mother cell (m) and haustorium (h) in a mesophyll cell. Fluorescence and differential interference contrast superimposed. B, Overexposure of image reveals weakly labeled intercellular hyphae (ih) beside two strongly labeled haustoria (h). C, Sporulating lesion with palisade parenchyma cells (pa), basal hyphae (bh), pedicels (pd), and newly formed uredospores (s). Only basal hyphae and haustoria are labeled. Fluorescence and phase contrast superimposed. Antiserum dilution was 1:500. Scale bars: $10 \mu \mathrm{m}$. 
growth-limiting metabolites. Thus, we speculate that the nearobligate nature of biotrophy in rust fungi could be due to the fact that differentiation of functional haustoria, which occurs only in living plant cells, is indispensable for effective growth.

\section{MATERIALS AND METHODS}

\section{Cultivation and manipulation of plant and rust fungus.}

Cultivation of broad bean plants (Vicia faba cv. con Amore) and inoculation with Uromyces fabae race $\mathrm{I}_{2}$ uredospores were done as described (Hahn and Mendgen 1997). Germinated spores and in vitro-grown infection structures were obtained as described (Deising et al. 1991; Hahn and Mendgen 1997).

Thiamine treatments of rust infection structures and infected leaves were done as follows: Spores settled on scratched polyethylene membranes were sprayed with $100 \mu \mathrm{M}$ thiamine $/ \mathrm{HCl}$ or water, and incubated for $24 \mathrm{~h}$ at $20^{\circ} \mathrm{C}$ in the dark to allow infection structure formation. Broad beans leaves were spray inoculated with spores, and after $24 \mathrm{~h}$, while being attached to the plant, infiltrated by pressing liquid with a blunt-ended syringe until they looked completely water soaked. The infiltration was repeated daily until 6 days post inoculation (dpi), and the leaves harvested 7 dpi. Infiltration was done with various concentrations of thiamine, or with water only. Another control plant remained untreated after inoculation.

\section{Nucleic acid manipulations and plasmid constructions.}

RNA isolations from rust-infected leaves, $U$. fabae infection structures, and isolated haustoria (Hahn and Mendgen 1992), and Northern (RNA) blot hybridization with digoxigenin-labeled DNA probes (Hahn and Mendgen 1997), were performed as described.

For complementation of fission yeast thiamine mutants, a 1,339-bp, near-full-length THI2 cDNA was ligated as an EcoRI fragment into the Schizosaccharomyces pombe expression vector pSAP-E (Truernit et al. 1996), resulting in the THI2-expressing plasmid pSAP-E-THI2. In the plasmid pSAP-E-THI2inv, the fragment was inserted in the opposite orientation. For expression of the corresponding THII constructs, the EcoRI cloning site of the vector pSAP-E was converted into a NotI site by EcoRI digestion followed by blunting and ligation to a NotI linker (Stratagene, La Jolla, CA), resulting in the new vector $\mathrm{pSAP}-\mathrm{N}$. Into this vector, a 1,412bp, near-full-length THII cDNA obtained from a haustoriumspecific $\lambda$ gt10 cDNA library (Hahn and Mendgen 1997) was ligated as a Not I fragment in both orientations, resulting in plasmids pSAP-N-THII (expressing) and pSAP-N-THIIinv (nonexpressing).

For overexpression of the THII encoded protein in E. coli, another THII clone of the haustorial cDNA library (cloned as a 1,426-bp SmaI fragment into plasmid pTZ19R) was amplified by PCR, with the sequence GAGATTCCTTCGTGC CATATGTCTACCGA as $5^{\prime}$ terminal primer, which contains an NdeI site (underlined) including the putative THII start codon. The amplification product was digested with NdeI plus HindIII and the resulting 1,360-bp fragment ligated into NdeI plus HindIII-digested pET28a(+) (Novagen, Madison, WI). The resulting plasmid, pTHIEXP1, expressed the complete THI1 protein, fused upstream to 20 vector-encoded amino acids including a 6 xHis tag.
To produce templates for sequencing, the genomic clones $\lambda$ EMBL3-THI1 and $\lambda$ EMBL3-THI2 were digested with HindIII and BamHI, respectively. A 4.0-kb HindIII fragment containing THII and a $3.9-\mathrm{kb}$ BamHI fragment containing THI2 were each ligated into pTZ19R (Amersham Pharmacia Biotech, Uppsala, Sweden). Sequencing was performed with fluorescently labeled ddNTP terminators and "walking" primers, with a 377 ABI sequencer (PE Applied Biosystems, Foster City, CA).

Determination of transcriptional start sites of THII and THI2 was done by primer extension analysis (Ausubel et al. 1995). Primer labeling was performed in $10 \mu \mathrm{l}$ with $10 \mathrm{pmol}$ of primer (THIl: TGAGAAGAACTGAAATTTTATCGGTA GACA; THI2: TGAGCAGTTTGATTGATAGTAGTAGGT TTG), $30 \mu \mathrm{Ci}$ adenosine $5^{\prime}-\left[\gamma^{32} \mathrm{P}\right]$ triphosphate, T4 polynucleotide kinase buffer, and $15 \mathrm{U}$ of $\mathrm{T} 4$ polynucleotide kinase (New England Biolabs, Beverly, CA), for $1 \mathrm{~h}$ at $37^{\circ} \mathrm{C}$ and stopped by $5 \mathrm{~min}$ of incubation at $65^{\circ} \mathrm{C}$. The solution was precipitated three times with $200 \mu \mathrm{l}$ of acetate buffer $(0.5 \mathrm{M}$ ammonium acetate, $10 \mathrm{mM}$ EDTA) and $500 \mu \mathrm{l}$ of ethanol and the resulting pellet dissolved in $50 \mu \mathrm{l}$ of water. The primer extension reactions were carried out with $10 \mu \mathrm{g}$ of poly(A)-RNA from rust infected leaves ( $6 \mathrm{dpi})$, and from noninfected control leaves. After annealing of the primer to the RNA in hybridization solution at $30^{\circ} \mathrm{C}$ overnight, the nucleic acids were ethanol precipitated, and the pellet dissolved in $20 \mu \mathrm{l}$ of solution containing AMV-Buffer, $1 \mathrm{mM}$ dNTPs, $24 \mathrm{U}$ of RNasin ribonuclease inhibitor, and $4 \mathrm{U}$ of $\mathrm{AMV}$ reverse transcriptase (Promega, Madison, WI). After incubation at $42^{\circ} \mathrm{C}$ for $1 \mathrm{~h}$, the reaction was stopped by addition of $1 \mu \mathrm{l}$ of $0.5 \mathrm{M}$ EDTA and 1 $\mu \mathrm{l}$ of RNaseA $(10 \mu \mathrm{g} / \mu \mathrm{l})$ and incubation at $37^{\circ} \mathrm{C}$ for $30 \mathrm{~min}$. After phenol extraction and ethanol precipitation, the DNA was dissolved in loading buffer and separated on a $6 \%$ polyacrylamide sequencing gel. For the sequencing reactions, the T7-Sequenase V.2.0 kit (Amersham) was used.

\section{Fission yeast methods.}

The $S$. pombe strains thi2-22(-), thi3-1(-) (Zurlinden and Schweingruber 1992), and leul-32(+) were obtained from M. E. Schweingruber, Bern. All strains were cultivated at $30^{\circ} \mathrm{C}$ on minimal medium plates with the required supplements (Schweingruber and Edenharter 1990). With the protocol of Alfa et al. (1993), the leu mutant gene was crossed into the thi mutants, resulting in strains thi2-22 leul-32 and thi3-1 leul-32. Plasmid transformation was done according to Okazaki et al. (1990). Transformants containing pSAP-E, pSAP-N, and their recombinant derivatives were selected on minimal medium agar plates without leucine, and subsequently tested for growth in the presence or absence of $50 \mathrm{nM}$ thiamine.

Expression of His-tagged THI1p and antibody generation.

Overexpression of the recombinant, His-tagged THI1 protein encoded by plasmid pTHI1EXP1 (see above) was done with E. coli BL21(DE3) and induction with $0.5 \mathrm{mM}$ isopropyl- $\beta$-D-thiogalactoside (Studier and Moffatt 1986). A onestep purification of THI1p was performed with immobilized metal ion affinity chromatography under denaturing conditions, according to the protocol of the manufacturer (Clontech, Palo Alto, CA). The protein was rebuffered in TBS (10 mM Tris/HCl, $150 \mathrm{mM} \mathrm{NaCl}, \mathrm{pH}$ 7.4) and used for the immuniza- 
tion of a rabbit. In immunoblots, the antiserum specifically recognized the THI1 protein whereas the preimmune serum did not.

\section{Protein extraction and immunoblot analysis.}

Spores were ground in a mortar with sea sand in $200 \mathrm{mM}$ Tris/ $\mathrm{HCl}, \mathrm{pH} 7.4$ at $4^{\circ} \mathrm{C}$. Isolated haustoria were ground without sea sand in the same buffer. Rust infection structures grown on polyethylene membranes were sprayed with $1.5 \mathrm{ml}$ of buffer $(50 \mathrm{mM}$ ammonium acetate, $1 \mathrm{mM}$ PMSF [phenylmethylsulfonyl fluoride], $1 \mathrm{mM}$ dithioerythreitol) and collected by scraping. The infection structures were homogenized on ice for 2 min with a polytron homogenizer (Ultraturrax T4; Janke \& Kunkel, Staufen, Germany). Leaf tissue was ground in liquid nitrogen and dissolved in $10 \mathrm{mM}$ Tris/ $\mathrm{HCl}, \mathrm{pH} 7.4$. The resulting homogenates were centrifuged $(16,000 \times g, 5$ $\left.\min , 4^{\circ} \mathrm{C}\right)$. The clear supernatants were subjected to sodium dodecyl sulfate-polyacrylamide gel electrophoresis (SDSPAGE; Laemmli 1970). Immunoblots were performed according to Towbin et al. (1979), with $15.6 \mathrm{mM}$ Tris, $120 \mathrm{mM}$ glycine, $20 \%$ (vol/vol) methanol, as electrode buffer. Proteins were electrotransferred to an Immobilon-P membrane (Millipore, Bedford, MA), probed with rabbit anti-THI1p serum, and visualized with a peroxidase-coupled goat anti-rabbit secondary antibody and ECL Western Blot Detection Reagent (Amersham).

\section{Immunofluorescence microscopy.}

Rust-infected leaf pieces ( $8 \mathrm{dpi}$ ) were vacuum infiltrated with $8 \%(\mathrm{vol} / \mathrm{vol})$ methanol in water, high pressure frozen with the HPM 010 instrument (Balzers, Liechtenstein) and freeze substituted as described (Mendgen et al. 1991). Specimens were embedded in a resin consisting of $75 \%$ butyl methacrylate and $25 \%$ methyl methacrylate, $0.5 \%$ benzoin ethyl ether, and $10 \mathrm{mM}$ dithiothreitol. The resin was infiltrated in mixtures with acetone $(25,50,75,100 \%$ resin) for 1 day each at $4^{\circ} \mathrm{C}$. Polymerization took place at $4^{\circ} \mathrm{C}$ during 4 days under UV light. Sections were treated with acetone for $30 \mathrm{~s}$, and three times for $15 \mathrm{~min}$ with blocking buffer $(0.1 \%$ [wt/vol] bovine serum albumin in TBS $[10 \mathrm{mM}$ Tris/ $\mathrm{HCl}, 150 \mathrm{mM}$ $\mathrm{NaCl}, \mathrm{pH}$ 7.4]) and incubated with anti-THI1p serum (1:500) in TBS for $2 \mathrm{~h}$. To detect nonspecific binding, the pre-immune serum was used as control. After three washes for $15 \mathrm{~min}$ in TBS, sections were incubated with the secondary antibody (cyanin-3-conjugated goat-anti-rabbit; Rockland, Gilbertsville, PA), diluted 1:400 with TBS, for $1 \mathrm{~h}$ at $20^{\circ} \mathrm{C}$. Samples were examined with a Zeiss Axioplan 2 microscope equipped for epifluorescence (filters BP 490, FT 510, LP565) with phase contrast, Nomarski differential interference contrast or fluorescence. Images were taken with Fujicolor 800 (Tokyo), digitized with an HP Photosmart Fotoscanner S20 (HewlettPackard, Palo Alto, CA) and superimposed with Photoshop software (Adobe Systems, Mountain View, CA).

\section{ACKNOWLEDGMENTS}

We are grateful to Heinz Vahlenkamp for expert technical assistance with immunocytology. We thank Ernst Schweingruber, University of Bern, for providing the $S$. pombe thiamine mutants, and Norbert Sauer, Erlangen, for the vector pSAP-E. The work was funded by grants from the Deutsche Forschungsgemeinschaft (Me 523/14-1; Ha 1486/2), and by the Fonds der Chemischen Industrie.

\section{LITERATURE CITED}

Alfa, C., Fantes, P., Hyams, J., McLeod, M., and Warbrick, E. 1993. Pages 577-580 in: Experiments with Fission Yeast. A Laboratory Course Manual. Cold Spring Harbor Laboratory, Cold Spring Harbor, NY.

Aked, J., and Hall, J. L. 1993. Effect of powdery mildew infection on concentrations of apoplastic sugars in pea leaves. New Phytol. 123: 283-288.

Ausubel, F. M., Brent, R., Kingston, R. E., Moore, D. D., Seidman, J. G., Smith, J. A. and Struhl, K. 1995. Current Protocols in Molecular Biology. John Wiley \& Sons, New York.

Baka, Z. A., Larous, L., and Loesel, D. M. 1995. Distribution of ATPase activity at the host-pathogen interfaces of rust infections. Physiol. Mol. Plant Pathol. 47:67-82.

Cary, J. W., and Bhatnagar, D. 1995. Nucleotide sequence of a Aspergillus parasiticus gene strongly repressed by thiamine. Biochim. Biophys. Acta 1261:319-320.

Coffey, M. D., and Shaw, M. 1972. Nutritional studies with axenic cultures of the flax rust, Melampsora lini. Physiol. Plant Pathol. 2:37-46.

Coleman, M., Henricot, B., Arnau, J., and Oliver, R. P. 1997. Starvationinduced genes of the tomato pathogen Cladosporium fulvum are also induced during growth in planta. Mol. Plant-Microbe Interact. 10: 1106-1109.

Deising, H., Jungblut, P. R., and Mendgen, K. 1991. Differentiationrelated proteins of the broad bean rust fungus Uromyces viciae-fabae, as revealed by high resolution two-dimensional polyacrylamide gel electrophoresis. Arch. Microbiol. 155:191-198.

Enjo, F., Nosaka, K., Ogata, M., Iwashima, A., and Nishimura, H. 1997. Isolation and characterization of a thiamin transport gene, THI10, from Saccharomyces cerevisiae. J. Biol. Chem. 272:19165-19170.

Farrar, J. F., and Lewis, D. H. 1987. Nutrient relations in biotrophic infections. Pages 92-132 in: Fungal Infection of Plants. G. F. Pegg and P. G. Ayres, eds. Cambridge University Press, Cambridge.

Fasters, M. K., Daniels, U., and Moerschbacher, B. M. 1993. A simple and reliable method for growing the wheat stem rust fungus, Puccinia graminis f. sp. tritici, in liquid culture. Physiol. Mol. Plant Pathol. 42: 259-265.

Hahn, M., and Mendgen, K. 1992. Isolation by ConA binding of haustoria from different rust fungi and comparison of their surface qualities. Protoplasma 170:95-103.

Hahn, M., and Mendgen, K. 1997. Characterization of in planta-induced rust genes isolated from a haustorium-specific cDNA library. Mol. Plant-Microbe Interact. 10:427-437.

Hahn, M., Neef, U., Struck, C., Göttfert, M., and Mendgen, K. 1997. A putative amino-acid transporter is specifically expressed in haustoria of the rust fungus Uromyces fabae. Mol. Plant-Microbe Interact. 10: 438-445.

Heath, M. C., and Skalamera, D. 1997. Cellular interactions between plants and biotrophic fungal parasites. Adv. Bot. Res. 24:195-225.

Hohmann, S., and Meacock, P. A. 1998. Thiamin metabolism and thiamin diphosphate-dependent enzymes in the yeast Saccharomyces cerevisiae: genetic regulation. Biochim. Biophys. Acta 1385:201-219.

Laemmli, U. K. 1970. Cleavage of structural proteins during the assembly of the head of bacteriophage T4. Nature 227:680-685.

Lohaus, G., Winter, H., Riens, B., and Heldt, H. W. 1995. Further studies of the phloem loading process in leaves of barley and spinach. The comparison of metabolite concentrations in the apoplastic compartment with those in the cytosolic compartment and in the sieve tubes. Bot. Acta 108:270-275.

Manetti, A. G., Rosetto, M., and Maundrell, K. G. 1994. nmt2 of fission yeast: A second thiamine-repressible gene co-ordinately regulated with $n m t 1$. Yeast 10:1075-1082.

Maundrell, K. 1990. nmt1 of fission yeast. J. Biol. Chem. 265:1085710864.

Mendgen, K. 1981. Nutrient uptake in rust fungi. Phytopathology 71: 983-989.

Mendgen, K., Welter, K., Scheffold, F., and Knauf-Beiter, G. 1991. High pressure freezing of rust infected plant leaves. Pages 31-42 in: Electron Microscopy of Plant Pathogens. K. Mendgen and D. E. Lesemann, eds. Springer Verlag, Berlin.

Okazaki, K., Okazaki, N., Kume, K., Jinno, S., Tanaka, K., and Okayama, H. 1990. High-frequency transformation method and library transducing vectors for cloning mammalian cDNAs by trans-comple- 
mentation of Schizosaccharomyces pombe. Nucleic Acids Res. 18: 6485-6489.

Patrick, J. W. 1989. Solute efflux from the host at plant-microorganism interfaces. Aust. J. Plant Physiol. 16:53-67.

Praekelt, U., and Meacock, P. 1992. MOL1, a Saccharomyces cerevisiae gene that is highly expressed in early stationary phase during growth on molasses. Yeast 8:699-710.

Schweingruber, M. E., and Edenharter, E. 1990. Thiamin regulates agglutination and zygote formation in Schizosaccharomyces pombe. Curr. Genet. 17:191-194.

Singleton, C. K. 1997. Identification and characterization of the thiamine transporter gene of Saccharomyces cerevisiae. Gene 199:111-121.

Spencer-Phillips, P. T. N., and Gay, J. L. 1981. Domains of ATPase in plasma membranes and transport through infected plant cells. New Phytol. 89:393-400.

Staples, R. C., and Macko, V. 1984. Germination of Urediospores and differentiation of infection structures. Pages 255-289 in: The Cereal Rusts, Volume I. W. R. Bushnell and A. P. Roelfs, eds. Academic Press, Orlando, FL.

Studier, F. W., and Moffatt, B. A. 1986. Use of bacteriophage T7 RNA polymerase to direct selective high-level expression of cloned genes. J. Mol. Biol. 189:113-130.

Talbot, N. J., McCafferty, H. R. K., Ma, M., Moore, K., and Hamer, J. E. 1997. Nitrogen starvation of the rice blast fungus Magnaporthe grisea may act as an environmental cue for disease symptom expression. Physiol. Mol. Plant Pathol. 50:179-195.

Towbin, H., Staehelin, T., and Gordon, J. 1979. Electrophoretic transfer of proteins from polyacrylamide gels to nitrocellulose sheets: procedure and some applications. Proc. Natl. Acad. Sci. USA 76:43504354.

Truernit, E., Schmid, J., Epple, P., Illig, J., and Sauer, N. 1996. The sinkspecific and stress-regulated Arabidopsis STP4 gene: Enhanced expression of a gene encoding a monosaccharide transporter by wounding, elicitors and pathogen challenge. Plant Cell 8:2169-2182.

Williams, P. G. 1984. Obligate parasitism and axenic culture. Pages 399430 in: The Cereal Rusts, Volume I. W. R. Bushnell and A. P. Roelfs, eds. Academic Press, Orlando, FL.

Zurlinden, A., and Schweingruber, M. E. 1992. Cloning and regulation of Schizosaccharomyces pombe thi2, a gene involved in thiamine biosynthesis. Gene 117:141-143. 